\title{
Voters are not fools, or are they? Party profile, individual sophistication and party choice
}

\author{
DOMINIK GERBER*, SARAH NICOLET AND PASCAL SCIARINI \\ Department of Political Science and International Relations, University of Geneva, Genève, Switzerland
}

\begin{abstract}
This article builds on V.O. Key's postulate that voters are not fools and that they function as an echo chamber reflecting the clarity of alternatives presented to them. We first propose a reassessment of Key's claim by examining whether and to what extent the impact of issue preferences on the vote choice depends on the clarity of parties' profile on these issues. Our empirical tests are based on data from the 2007 Swiss election study and cover three different issues that voters may use as decision-making criteria. Our results confirm that the clearer a party's profile on a given issue, the higher the impact of that issue on the vote for the party. Second, we offer a refinement of Key's argument by arguing that voters' political sophistication conditions the strength of issue voting. Empirical evidence supports this argument, but shows that the effect of political sophistication is curvilinear: sophistication exerts a stronger mediating role when a party has a moderately clear profile than when it has a low or high profile.
\end{abstract}

Keywords: party choice; party profile; political sophistication; Switzerland

\section{Introduction}

In the late 1960s, V.O. Key in his famous posthumous book The Responsible Electorate took the defence of the electorate, often scorned for its lack of political skills and rationality. According to Key (1966: 7), voters were not fools. To the contrary, '.. in the large the electorate behaves about as rationally and responsibly as we should expect, given the clarity of the alternatives presented to it and the character of the information available'. In Key's view (1966: 2), the electorate functions as an 'echo chamber' reflecting the alternatives presented to it by the political parties. In other words, Key shifted the blame for a lack of sophistication in voting decisions from the voters to the parties. If parties did not provide voters with clear political choices, these same voters could not possibly cast a politically informed vote.

In this article we use V.O. Key's postulate as a starting point, and we pursue two objectives. First, we propose a reassessment of Key's claim by examining to which extent voters' decision-making mechanisms are conditional upon the political alternatives provided by the competing parties. To this purpose, we analyse how the impact of issue preferences on the vote choice depends on the clarity of party profile.

*E-mail: dominik@dominikgerber.eu 
We hypothesize that the clearer the party profile with respect to a given issue, the higher the influence of this issue on the vote choice. It is easier for voters to evaluate a party that has a clear profile on a given issue, than a party that has an indistinct and/or ambiguous position. Therefore, voters are more likely to base their party choice on an issue if the party profile on that issue is clear, than if it is unclear. By looking at the conditional role of party profile, we contribute to the literature emphasizing the impact of party characteristics on the vote choice (van der Eijk and Franklin, 1996; Alvarez and Nagler, 1998; Franklin and De Sio, 2012; Walczak and van der Brug, 2012).

Second, we offer a refinement of Key's argument by arguing that the effects of issue voting do not only depend on the clarity of parties' profiles, but also on voters' characteristics. Voters differ from each other with respect to political sophistication (e.g. Converse, 1964; Page and Shapiro, 1992; Delli Carpini and Keeter, 1996; Kuklinski et al., 2001), and they are thus not all equally likely to be knowledgeable about the alternatives defended by parties. Depending on their level of political sophistication, they will have more or less trouble identifying parties' positions and using them when making their electoral choice. More specifically, we expect political sophistication to exert a mediating effect on the use of the various issue criteria in interaction with the clarity of party profile: if a party has a clear profile on a given issue, even the less sophisticated voters will be able to judge that party and to use the corresponding issue as a criterion when forming their opinion. By contrast, if a party profile is unclear, voters will have a hard time evaluating the party. In such a situation, only the most sophisticated voters will be able to figure out the party's position. The less sophisticated voters will not. According to our second hypothesis, then, if the clarity of a party's profile on a given issue is low, the higher the political sophistication the stronger the impact of that issue on party choice.

We test our hypotheses on data from the 2007 Swiss election study, whereby we combine data from a post-electoral survey among voters and a pre-electoral survey among candidates. The post-electoral survey enables us to measure the different variables that are relevant for our inquiry. It includes information regarding three different issues that voters may use as decision-making criteria (two issue-specific measures about economic redistribution and international openness, and a more encompassing measure of issue conflict), their level of political sophistication, and their propensity to vote for the different parties: propensity to vote is our measure of party choice and it is the key outcome of our analysis. In addition, to measure the clarity of party profile we rely on data from the comparative candidate survey (CSS), and we apply them to the five main Swiss parties, namely the four governing parties and the Greens.

Switzerland can be seen as a 'hard case' with respect to the effects of party profile and issue voting. First, in the Swiss 'consensus democracy' (Lijphart, 1999; Vatter, 2009), the importance of power sharing mechanisms, most evident in the inclusive character of its executive power, ${ }^{1}$ has tended to narrow down the ideological

1 The same four main political parties have formed the governing coalition for the last 5 decades. 
differences between parties. Second, by enabling citizens to vote on specific issues several times a year, direct democracy is said to reduce the influence of issue voting on electoral choice (Schloeth, 1998; Holzer and Linder, 2003). Therefore, if our hypotheses regarding party profile and issue voting hold in Switzerland, we can be confident that they do so in other countries as well.

The remainder of the article is structured as follows. Section two presents our research hypotheses in more detail. The data, the operationalization and the model are presented in section three. The empirical tests appear in section four. Section five concludes and highlights the broader implications of our findings.

\section{Theoretical framework}

When studying party support the standard approach is to focus on the characteristics of voters. In this article we join the literature arguing that one should go beyond this voter-centric focus and take into account party characteristics when modelling electoral choice (van der Eijk and Franklin, 1996; Alvarez and Nagler, 1998; Franklin and De Sio, 2012; Walczak and van der Brug, 2012).

Political parties differ from each other in a number of dimensions (e.g. their size, their length of existence, their legislative weight, their government status, their ideology, etc.). In this paper, we focus on a party characteristic that has scarcely been addressed so far: The clarity of party profile on political issues. We investigate whether, to what extent and under which conditions voters use issues as decisionmaking criteria when evaluating political parties. According to our general assumption, the impact of issue preferences on the vote choice depends on the clarity of parties' profiles on these issues.

We further contribute to the existing literature by bringing voters' characteristics into the analysis. Voters differ in terms of political sophistication and are, therefore, not likely to go through the same process of party choice formation. By looking at the strength of issue voting across parties and across voters our article innovates, as it integrates both supply side (party profile) and demand side (political sophistication) variables into a comprehensive framework. In the next two sub-sections we elaborate on the role of party profile before adding voters' political sophistication.

\section{The role of party profile clarity}

The importance of meaningful political alternatives as a determinant of electoral behaviour was first emphasized by V.O. Key (1966). In his view, parties set the agenda for the contest and define the political options from which voters can choose. They provide voters with meaningful choices if they defend distinctive political positions: Differences in parties' positions provide the necessary yardstick against which citizens can locate their own preferred position, and, on this basis, pick the party closest to their own political preferences. In this view, there must be some sort of dissent between political parties, for example on a given political issue 
in order for voters to base their party choice on this issue. If there is consensus, then voters will not be able to position themselves based on issue preferences, and the issue will not affect their vote.

While Key (1966) developed his theoretical argument regarding the clarity of alternatives at the party system level, we apply the argument at the level of individual parties, addressing it through the concept of party profile clarity. Both concepts ('clear alternatives' and 'clear party profile') are obviously closely linked, since there can be clear alternatives only if parties have clear and distinctive profiles. In analogy with several studies in the field of issue voting (e.g. Kriesi and Sciarini, 2004; de Vries, 2010) our definition of the clarity of party profile comprises two elements: the distinctiveness of a party's position on a given issue, and the cohesiveness of the party's position, that is, the existence of a strong unity within the party regarding that issue.

Distinctiveness is the first factor accounting for the clarity of party profile, and is most directly in line with Key's (1966) intuition. We argue that a party is clearly profiled if it takes a distinctive stance on a given issue, that is, a stance that unambiguously distinguishes the party from its competitors. According to this definition, it is not the intensity or extremity of a party's position that matters, but its distinctiveness or uniqueness. Theoretically, a party that holds moderate preferences on a given issue may still be clearly profiled, provided it offers a clear alternative to voters, that is, provided its preferences are different from those of its main competitors. In that sense, our conception departs from the directional model of issue voting (Rabinowitz and MacDonald, 1989; Rabinowitz et al., 1995), as it neither grants a premium to parties with extreme positions, nor prejudices parties with more moderate or centrist positions. Empirically, however, centrist parties may have a hard time differentiating themselves, since they face double competition from parties on both their right and left (see below). On the other hand, our model also differs from the classic proximity model (Downs, 1957; Enelow and Hinich, 1984), since it is agnostic with respect to the median voter theorem: It does not predict a race to the median voter, but offers no premium to more radical parties either.

While Key's (1966) argument is all about the clarity of alternatives and the related distinctiveness of party profiles, we go one step further and claim that internal unity is also crucial: to provide clear alternatives, a party must not only defend a distinctive position, but also be internally united. This is the second component of our definition, and emphasizes the importance of a party's cohesiveness for the clarity of signals sent to voters. Internal dissent is thus seen to have the same consequences as a lack of a distinctive position, that is, it would result in ambivalent and blurred messages (de Vries, 2010: 95). Ambivalent and blurred messages, in turn, would affect the ability of voters to evaluate the party. In sum, according to our definition, a clear profile on a given issue means both that the party offers a distinctive alternative and enjoys high internal unity on that issue. ${ }^{2}$

\footnotetext{
${ }^{2}$ Note that party profile clarity should not be confused with the clarity of responsibility. The latter applies to a governing party and refers to the evaluation of a government success, whereas the former
} 
The motivations behind parties' attempts to profile themselves on specific issues are at the centre of theories of 'selective emphasis' (Budge and Farlie, 1983) or 'issue ownership' (Petrocik, 1996). According to this perspective, each party 'owns' some issues, meaning that it is seen as being more competent and able than its rivals at managing them (Petrocik, 1996; van der Brug, 2004). Parties competing in an electoral campaign attempt to emphasize those issues on which they have a comparative advantage and to minimize the importance of those on which their adversaries are perceived to be stronger. As a result, parties are said to be evaluated by voters on the basis of the issues that figure prominently on their political platforms and on which they have a clear profile.

The argument of issue ownership theory, that is, that parties focus their campaign on the issues they 'own', has been questioned by the issue competition literature (e.g. Green-Pedersen, 2007).

This literature acknowledges that parties emphasize issues which they would like to see dominate electoral competition, but claims that issue competition does not imply that parties will each select one or a few issues and then simply ignore all others. To the contrary, issue competition may force parties to pay attention to issues that are owned by other parties.

In spite of their differences the issue ownership and the issue competition literature are both premised on the idea that parties need to profile themselves on issues. Seen from the perspective of electoral choice, this means that issues on which parties adopt clear positions are likely to be used by voters as criteria for their vote choice; by contrast, issues on which party profiles are unclear, that is, issues on which parties have an indistinctive and/or ambiguous position, are unlikely to rank high among voters' standards of judgement. Thus, parties that make clear proposals on international issues will be evaluated mainly on this basis by electors, whereas preferences relating to social policy will be central for judging parties that position themselves clearly on this topic.

According to our first hypothesis, then, the strength of issue voting depends on the clarity of party profile: The clearer a party's profile on a given issue, the more likely it is that this issue will influence the vote for that party.

\section{The joint effect of party profile and political sophistication}

Up to now we have hypothesized about the influence of party profile clarity on electoral choice, that is, we have focused on the 'supply side'. We still need to take into account, on the 'demand side', the role played by voters' characteristics. As several studies have shown, voters are not all uniformly sophisticated with respect to politics (e.g. Converse, 1964; Page and Shapiro, 1992; Delli Carpini and Keeter, 1996), and they do not all

concerns any single party and is not meant as an evaluation of past performance. The distinction between 'clarity of profile' and 'clarity of responsibility' is all the more important in the Swiss consensus democracy, where it is especially difficult to attribute responsibility, since all major political parties are members of the governing coalition. 
follow the same process of electoral choice (e.g. Rivers, 1988; Sniderman et al., 1990; Zaller, 1992). ${ }^{3}$ Accordingly, we argue that differences in voters' political sophistication affect their ability to evaluate parties' positions. Sophisticated voters who are well informed about politics will know - at least approximately - where each party stands on the main issues and policies and will, therefore, be able to base their choice on the related decision-making criteria. Politically unaware voters, by contrast, lack the basic political knowledge to enable them to correctly identify party positions.

We thus assume that political sophistication regulates the formation of party choice in interaction with the clarity of party profiles. If a party has a clear issue profile, political sophistication is unlikely to make a difference. In such a situation, even political novices will know the party's position on the issue at stake and will, therefore, be able to judge based on that issue. By contrast, if a party's profile is indistinctive or blurred, only political experts will be able to figure out the unclear party position. According to our second hypothesis, then, for parties with an unclear issue profile, the higher the political sophistication the stronger the impact of that issue on electoral choice; no such mediating effect is expected for clearly profiled parties.

In other words, we assume that a clear party profile may compensate for differences in sophistication between voters. This refinement fits well with the spirit of Key's argument: if parties offer true choices, then voters will not behave like 'fools', since even political novices will be able to make a reasonable decision. It is only when parties do not provide citizens with clear choices that there is a risk that less sophisticated voters will vote 'at random'.

We can now summarize our hypotheses:

HYPOTHESIS 1: The clearer the issue profile of a party, the higher the impact of that issue on its vote.

HYPOTHESIS 2: Political sophistication influences the process of electoral choice in interaction with the clarity of party profile: when the party's profile on a given issue is unclear, the higher the voter's sophistication the stronger the impact of that issue on his/her vote for that party; when a party's profile is clear, the impact of the issue on the vote choice will not differ between novices and experts.

\section{Operationalization and models}

\section{Demand-side variables}

Our data stems from a post-election survey carried out in the context of the 2007 Swiss election study on a representative sample of the Swiss electorate

\footnotetext{
${ }^{3}$ For Switzerland, see for example Lachat and Sciarini (2002), Lachat (2007), Nicolet and Mendicino (2010).
} 
(4392 interviews). ${ }^{4}$ Our dependent variable is the probability of a vote for each of the five main Swiss parties - the four governing parties (the Social Democratic party, the Christian Democratic party, the Radical Democratic party, and the Swiss People's party) and the Greens. ${ }^{5}$ Voting probability (or 'propensity') is more in line with the analytical focus on party choice formation than the classic measure of party choice (see van der Eijk and Franklin, 1996, van der Eijk et al., 2006, van der Brug et al., 2007). Respondents were asked to indicate on a 0-10 scale how likely it was that they would ever vote for a given party. Scales were then recoded into a 0-1 range.

Turning to the independent variables, our operationalization of issues covers the two most important dimensions of conflict among Swiss parties (Kriesi et al., 2008; Nicolet and Sciarini, 2010): The classic, economic (or 'redistributive') conflict over market forces, social justice and state intervention; and the new, cultural conflict regarding the desired level of international 'openness' vs. 'closedness' (or 'integration' vs. 'demarcation') of the country (Brunner and Sciarini, 2002; Kriesi et al., 2008). Survey respondents were asked to indicate both their own issue position and that of each of the five main parties on a 5-point scale (from strongly in favour to strongly against a given policy proposal). From that we computed the distance between a respondent and a party. Our indicator of the economic, redistributive dimension is based on a question regarding taxes on high income, whereas our measure of international openness is based on a question regarding Switzerland's EU membership. EU membership has been a central issue in Swiss politics since the early 1990s, and the main component of the larger 'globalization conflict' (Kriesi et al., 2008).

In addition to these two issue-specific criteria, we include a third, more encompassing measure of issue conflict. In Switzerland, as in other countries, the left-right scale offers a synthesis of the salient conflict lines existing in the party system, and more especially of the two conflict lines regarding economic redistribution and international openness mentioned above (Kriesi et al., 2008; Nicolet and Sciarini, 2010). Accordingly, we calculate the absolute distance between a respondent's selflocation on the $0-10$ left-right scale, and his/her perceived location of the five parties on the same scale.

Following the lead of earlier work showing that the quality of political judgments depends both on information and motivation (e.g. Berelson et al., 1954; Dalton, 1984; Neuman 1986; Kuklinski et al., 2001; Walczak and van der Brug, 2012), our conception of political sophistication includes a cognitive dimension and an

\footnotetext{
4 The data set is available for download at the following URL: http://fors-nesstar.unil.ch. The number of respondents who participated in the 2007 election, and on which we focus in this paper, is 3083.

5 The Green party is the largest non-governing party (10\% of the votes in 2007$)$ and the main competitor of the Social democrats (Bochsler and Sciarini, 2010). Taken together, the five main parties received more than $85 \%$ of the votes in the 2007 election - and more than $90 \%$ of the seats in the National Council, the lower Chamber of the Swiss parliament.
} 
affective dimension. The cognitive dimension pertains to people's knowledge about politics and to their understanding of the political sphere. The affective dimension deals with voter's motivation with respect to politics. Together, these two dimensions influence the ability of a voter to understand political affairs and to make a political choice.

The motivational dimension is operationalized by a measure of voters' general interest in politics, which distinguishes between a low, moderate, and high level of interest. For the cognitive dimension, we rely on four questions measuring factual knowledge of Swiss politics, which again led to a threefold categorization of knowledge (low, moderate, and high). ${ }^{6}$ The two resulting scales were recoded from 0 (low) to 2 (high) and then added, which led to an index ranging from 0 (no sophistication) to 4 (very high sophistication). ${ }^{7}$

In addition, we include a set of control variables (sex, age, level of education, social class, church attendance and residence location) found to exert an influence on electoral behaviour in Switzerland (e.g. Kriesi and Sciarini, 2004; Lutz, 2007).

\section{Supply-side variables}

On the supply side, our measure of party profile on the three issues under study (redistribution, openness, and left-right) stems from the 2007 comparative CSS, in which more than half $(54 \%)$ of the candidates in the Swiss national elections of 2007 participated. Based on this, we characterize the profile of the five political parties covered by our study on each of the three issues as either low, moderate, or high. Table 1 summarizes the classification. A systematic discussion of the coding appears in the online appendix.

According to our coding, the Swiss People's party is clearly profiled on all three issues. The Social Democratic party follows, with a clear profile on two issues and a moderate profile on one. The Christian Democrats have the least clear profile, whereas the Greens and the Radical Democrats occupy an intermediate position.

As mentioned above, in theory our definition of party profile neither rewards extreme parties nor prejudices centre parties. Empirically, however, it is obviously more difficult for a centre party to hold a distinctive position, as it faces the competition of parties on both the right and the left. This said, the low clarity profile of the two moderate right parties stems not only from their lack of distinctiveness, but also from their lack of cohesiveness. In any case, the fact that the two pole parties (the Social Democratic party and, even more so, the Swiss People's party) are those

\footnotetext{
6 The questions asked concerned (1) the number of parties represented in the Federal Council, (2) the name of the President of the Swiss Confederation, (3) the number of seats in the National Council of the respondent's home Canton, and (4) the number of signatures required to launch a popular initiative. 0-1 correct responses correspond to a 'low level', two to three correct responses to a 'moderate level', and four correct responses to a 'high level' of political knowledge.

7 The two dimensions (the knowledge scale and the motivation scale) correlate to a large extent $(R=0.45, N=4383)$. We ran additional tests focusing only on the cognitive dimension of our sophistication measure. The results remain the same (more on this in footnote 17).
} 
Table 1. Clarity of party profile

\begin{tabular}{llll}
\hline \hline & $\begin{array}{l}\text { EU membership issue } \\
\text { (international } \\
\text { openness) }\end{array}$ & $\begin{array}{l}\text { Fiscal issue } \\
\text { (redistributive) }\end{array}$ & $\begin{array}{l}\text { Left/right dimension } \\
\text { (synthesis of issue } \\
\text { conflict) }\end{array}$ \\
\hline Social Democratic party & High & High & Moderate \\
Green party & Moderate & High & Moderate \\
Christian Democratic party & Low & Low & Low \\
Radical Democratic party & Low & Moderate & Low \\
Swiss People's party & High & High & High \\
\hline \hline
\end{tabular}

with the clearest profiles will come as no surprise for analysts of Swiss politics. A firm stance on policy issues and a united party line are part and parcel of their electoral strategy (e.g. Kriesi and Sciarini, 2004).

\section{Models}

To analyse the effect of party profile and political sophistication on voting propensities, we estimate the two following models:

$$
\begin{gathered}
P_{i j p}=\beta_{0}+\beta_{1}\left|P_{j i}-P_{j p}\right|+\beta_{2} D_{j p}+\beta_{3} I_{j \times p^{\prime}}+\sum_{c=1}^{n} \beta_{c} c+\varepsilon \\
P_{i j p}=\beta_{0}+\beta_{1}\left|P_{j i}-P_{j p}\right|+\beta_{2} D_{j p}+\beta_{3} I_{j \times p^{\prime}}+\beta_{4} S_{i} \\
+\beta_{5} I_{j \times s}+\beta_{6} I_{p^{\prime} \times s}+\beta_{7} I_{j \times p^{\prime} \times s}+\sum_{c=1}^{n} \beta_{c} c+\varepsilon
\end{gathered}
$$

where $P_{i j p}$ is the propensity of voter $i$ to vote for party $p$ on issue $j,{ }^{8}\left|P_{j i}-P_{j p}\right|$ expresses the distance between voter $i$ 's and party $p$ 's position on issue $j, D_{j p}$ is the dummy variable of party p's profile on issue $j, S_{i}$ is voter $i$ 's level of political sophistication, and $c$ are control variables. Interaction terms are represented as $I$ with their respective constituents (issue $j$, party $p$ 's profile on $j$, and/or $i$ 's political sophistication) specified in the subscript. Model 1 will enable us to test the first set of hypotheses regarding the impact of party profile clarity on voting propensity, that is, how this clarity affects the extent to which an issue influences the vote choice. In model 2 we add the effect of political sophistication, by including a three-tier interaction term between political sophistication, issue, and party profile.

For both theoretical and empirical reasons, we run three different models (one for each of the three issues) rather than including the three issues in a single model. Theoretically, we are not interested in the relative weight of each issue in vote choice. ${ }^{9}$

\footnotetext{
${ }^{8}$ For comparative purposes we rescale all issue scales from 0 to 1.

${ }^{9}$ Similarly, we are not interested in testing how our three issues perform in comparison with alternative explanations of vote choice, such as party identification or trust in parties. Such a test is beyond the scope of this paper.
} 
Our primary goal is to evaluate whether and to what extent variations in the impact of an issue on vote choice is conditional on party profile clarity and voters' political sophistication. Empirically, initial estimations of a single model including the three issues revealed severe colinearity problems, which also called for separate estimations. Note that this problem does not stem from the three issues themselves, which do not correlate strongly, but from the complex set of interactions between issues, party profile and political sophistication. ${ }^{10}$

Given that we wish to look at the determinants of voting propensity for all five Swiss governing parties and to compare these determinants across parties, ${ }^{11}$ we reshaped the data set into a stacked format (van der Eijk and Franklin, 1996; see also Stimson, 1985; Tillie, 1995). By representing each respondent's answer on each party for which he/she was asked to indicate voting probability, we are able to simultaneously assess individual and inter-party variations in the formation of voting propensity. To correct for possible biases due to intra-cluster colinearity - the five observation units pertaining to one respondent are not necessarily independent from each other - we computed robust clustered standard errors using the Huber/ White/Sandwich estimate of variance (Huber, 1967; White, 1980).

In accordance with the basic logic of a stacked data set where the main units of analysis are 'respondent $\times$ party' relationships, we adapted the operationalization of all predictors to render them comparable across parties. For the issue variables this is easily implemented as they are all measured in terms of voter-party distance. For the other variables, which do not reflect distances, we follow van der Eijk and Franklin (1996) and inductively transform the original independent variables by performing, for each party and for each variable separately, a series of bivariate ordinary least square regressions, thus estimating each party's voting propensity as a function of the respective predictor. The predicted values of these regressions (y-hats) were then included in the stacked data set - and subsequently used as predictors of voting propensities.

\section{Empirical tests}

Table 2 presents the results of our estimations, with models 1 to 3 focusing on the impact of party profile and models 4 to 6 adding the effect of political sophistication. It should be noted, first, that the 'low clarity' and 'high clarity' variables appearing on the first two rows are dummies included to control for possible

${ }^{10}$ In the initial (non-stacked) data correlation between the three issue scales is low, varying between 0.11 and 0.35 . In the stacked data set the correlation between the three related voter-party distances is only slightly higher (0.17-0.37). In addition, the variance inflation factors (VIFs) of a fully specified model (including the three issues simultaneously) confirm that the colinearity problem stems from the complex set of interactions, not from the issues themselves.

${ }^{11}$ Such comparisons would be problematic if the impact of mediating determinants were assessed in a party-wise logic, that is were each of the five parties' voting chances analysed separately. Such a logic would only cover variation between individuals (intra-party variation) (see Van der Eijk and Franklin, 1996: 344). 
Table 2. Impact of issue criteria and political sophistication on voting propensity, non-standardized OLS coefficients (robust clustered standard errors in parenthesis)

\begin{tabular}{|c|c|c|c|c|c|c|}
\hline & $\begin{array}{c}\text { Model } 1 \\
\text { Ideology l-r }\end{array}$ & $\begin{array}{l}\text { Model } 2 \\
\text { EU issue }\end{array}$ & $\begin{array}{c}\text { Model } 3 \\
\text { Fiscal issue }\end{array}$ & $\begin{array}{c}\text { Model } 4 \\
\text { Ideology l-r }\end{array}$ & $\begin{array}{l}\text { Model } 5 \\
\text { EU issue }\end{array}$ & $\begin{array}{c}\text { Model } 6 \\
\text { Fiscal issue }\end{array}$ \\
\hline \multicolumn{7}{|l|}{ Clarity of profile (ref: moderate) } \\
\hline Low clarity & $-0.091 * * *(0.008)$ & $-0.095 *(0.020)$ & $-0.088 * * *(0.001)$ & $-0.094 * * *(0.008)$ & $-0.086^{*}(0.021)$ & $-0.083 * * *(0.001)$ \\
\hline High clarity & $-0.016(0.007)$ & $-0.004(0.012)$ & $-0.020 *(0.002)$ & $-0.016(0.007)$ & $0.003(0.013)$ & $-0.017 *(0.003)$ \\
\hline Issue criterion & $-0.763 * *(0.010)$ & $-0.334 * * *(0.005)$ & $-0.321 * * *(0.003)$ & $-0.757 * * *(0.008)$ & $-0.315 * *(0.004)$ & $-0.316 * *(0.002)$ \\
\hline Political sophistication & $0.541 *(0.155)$ & $0.553 * *(0.097)$ & $0.527(0.228)$ & $5.362 * * *(0.407)$ & $26.658 * *(0.971)$ & $1.457 * *(0.021)$ \\
\hline Sophistication $\times$ issue criterion & & & & $-11.645 *(1.280)$ & $-61.943 * *(1.038)$ & $-1.278 * *(0.012)$ \\
\hline \multicolumn{7}{|c|}{ Clarity of profile (ref: moderate) $\times$ issue criterion } \\
\hline Low clarity $\times$ issue criterion & $0.105 * *(0.009)$ & $0.141 *(0.055)$ & $0.146 * *(0.003)$ & $0.116 * * *(0.004)$ & $0.117 *(0.055)$ & $0.141 * *(0.002)$ \\
\hline High clarity $\times$ issue criterion & $-0.092 * * *(0.007)$ & $-0.141 *(0.060)$ & $-0.083 *(0.013)$ & $-0.096 * *(0.004)$ & $-0.160 *(0.057)$ & $-0.088 *(0.012)$ \\
\hline \multicolumn{7}{|c|}{ Clarity of profile (ref: moderate $) \times$ sophistication } \\
\hline Low clarity $\times$ sophistication & & & & $-3.786 *(0.407)$ & $-26.510 * *(0.996)$ & $-1.104 * *(0.023)$ \\
\hline High clarity $\times$ sophistication & & & & $-6.237 * *(0.430)$ & $-26.426 * *(0.638)$ & $-1.383 *(0.602)$ \\
\hline \multicolumn{7}{|c|}{ Clarity of profile (ref: moderate) $\times$ criterion $\times$ sophistication } \\
\hline Low clarity $\times$ issue $\times$ sophistication & & & & $7.828 *(1.316)$ & $62.759 * *(1.089)$ & $0.355 *(0.062)$ \\
\hline High clarity $\times$ issue $\times$ sophistication & & & & $14.020 * *(1.276)$ & $63.356 * *(1.063)$ & $1.608(1.299)$ \\
\hline Socio-demographic characteristic & \multicolumn{6}{|c|}{ Not displayed for space reasons } \\
\hline Constant & $0.727 * * *(0.006)$ & $0.651 * * *(0.001)$ & $0.631 * * *(0.001)$ & $0.726 * *(0.007)$ & $0.644 * *(0.001)$ & $0.628 * *(0.001)$ \\
\hline$R^{2}$ & 0.377 & 0.246 & 0.218 & 0.382 & 0.248 & 0.219 \\
\hline$N$ & 12,290 & 10,736 & 10,483 & 12,290 & 10,736 & 10,483 \\
\hline
\end{tabular}

OLS $=$ ordinary least square.

$* P<0.05 ; * * P<0.01 ; * * * P<0.001$; stacked SELECTS/2007 data, weighted for cantonal oversampling. Individuals who did not cast a vote have been excluded from the analysis. 
variations in voting propensities across levels of profile clarity. Second, the variable appearing on the third row (issue criterion) changes in each model: it represents the left-right dimension in models 1 and 4, the EU issue in models 2 and 5, and the fiscal issue in models 3 and 6 . The related coefficients inform about the impact of a given issue - or, more specifically, about the impact of the voter-party distance on that issue - on the propensity to vote for a party with a moderate profile (reference category). For example, the coefficient for 'issue' in model 1 indicates that the propensity to vote for a party with a moderate profile on the left-right scale decreases by 7.6 percentage points when the voter-party distance on that scale increases by one unit.

More important for our present purpose - and for the test of Hypothesis 1 - are the coefficients on the sixth and seventh rows. They relate to the interaction terms between an issue and party profile clarity on that issue, that is, they inform about the extent to which the impact of the issue criterion on the vote choice varies according to the clarity of a party's profile on that issue. Recall that according to our Hypothesis 1, issue preferences have a higher influence on electoral choice for parties with clear profiles. In line with this hypothesis, the influence of voter-party distance with respect to a given issue on the propensity to vote for a party is significantly stronger if the party has a clear profile on that issue than if the party has a moderately clear profile (reference category), and it is stronger in the latter case than when profile clarity is low. ${ }^{12}$ This result holds for both our synthetic measure of issue conflict (left-right, model 1) and our two issue-specific measures - EU membership (model 2) and taxes (model 3).

To get a finer-grained view of the effects, in Figure 1 we report the difference in the estimated propensity (and related confidence intervals) to vote for parties with low, moderate, and high profile clarity, as a function of the voter-party distance on the left-right scale, while keeping the control variables at their mean or at their reference value. ${ }^{13}$ For parties with weak, moderate, and high profiles the estimated vote propensity increases substantially as one moves from the largest to the smallest voter-party distance on the left-right dimension (i.e. from the right to the left of the horizontal axis). However, as demonstrated by the steepness of the curves, the effect of voter-party distance increases with the clarity of party profile: the difference in voting propensity reaches 80 percentage points for high profile clarity (from $0 \%$ to $80 \%$ ), against 70 percentage points for moderate profile clarity, and 60 percentage points for low profile clarity.

Party profile clarity matters even more with respect to the EU membership issue (Table 2, model 2). Figure 2 again helps to evaluate the magnitude of the

\footnotetext{
12 The positive sign of the coefficient for parties with low profile clarity means that the voter-party distance has a lower effect than for the reference category, that is, than for parties with a moderately clear profile.

13 The reference person of the plotted graphs is a 58-year-old male with low education, active as a nonindependent routine worker, residing in a town and with no church attendance.
} 


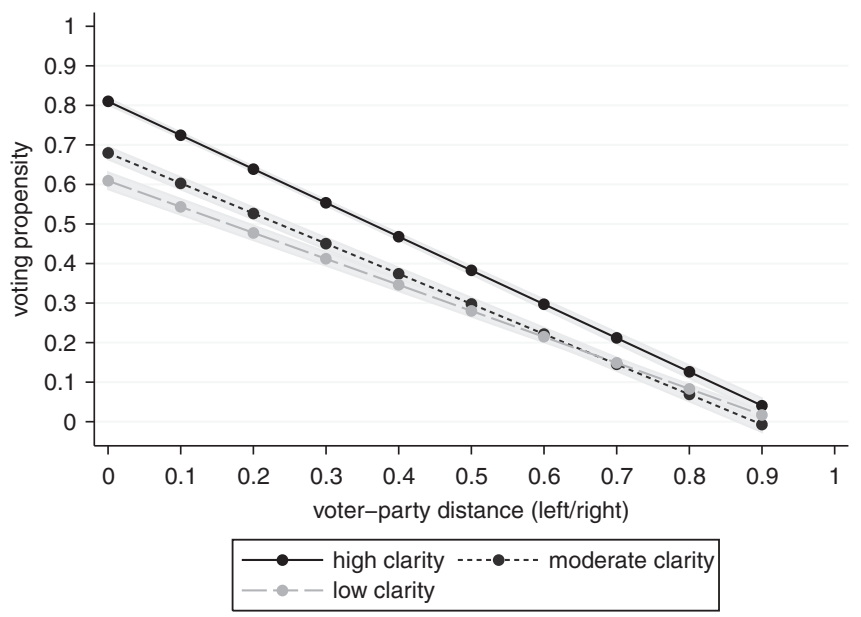

Figure 1 Left-right dimension: impact of voter-party distance on vote propensity, depending on party profile clarity. ${ }^{14}$

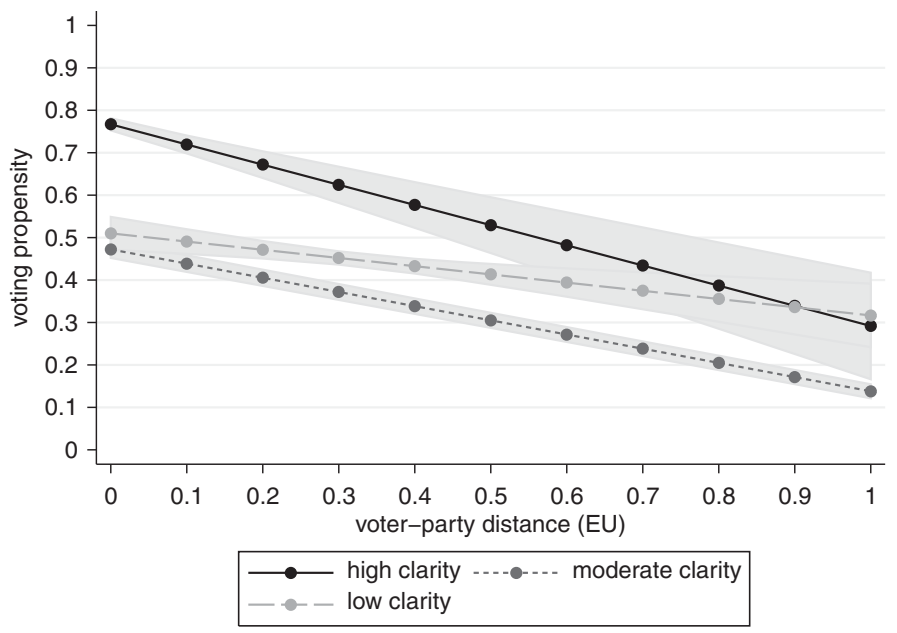

Figure 2 EU membership issue: impact of voter-party distance on vote propensity, depending on party profile clarity.

effect: While the propensity to vote for a party with an unclear profile increases by less than 20 percentage points as one moves from a maximal voter-party distance to

${ }^{14}$ We see that the estimated voting propensity falls below 0 when voter-party distance is maximal (higher than 0.9). This is not a problem, as these theoretical predictions depend on the characteristics of the reference person (see previous footnote). In addition, there are clearly very few individuals who share the characteristics of the reference person and who display a maximal distance with a given partyin our dataset. 


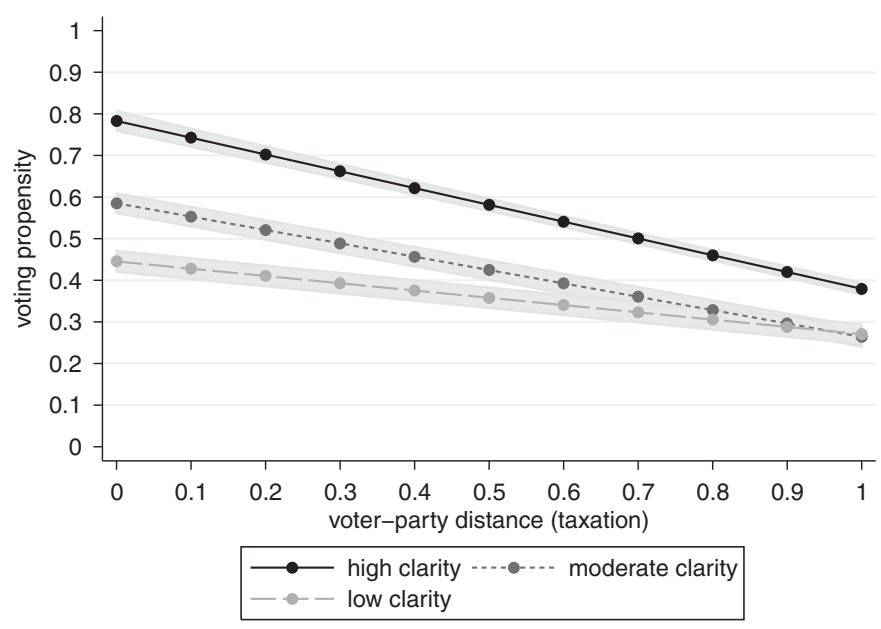

Figure 3 Fiscal issue: impact of voter-party distance on vote propensity, depending on party profile clarity.

a minimal voter-party distance with respect to EU membership, the corresponding difference exceeds 30 percentage points with moderate party profile clarity and 45 percentage points with high party profile clarity.

The differences according to party profile are also sizeable with respect to the fiscal issue (model 3 of Table 2, and Figure 3): While the propensity to vote for a party with low profile clarity on the fiscal issue increases by only 15 percentage points (from $30 \%$ to $45 \%$ ) as one moves from maximal voter-party distance to perfect voter-party proximity on that issue (i.e. the difference between the two extreme categories), the corresponding differences amounts to 30 percentage points for parties with moderate profile clarity and reaches 40 percentage points for parties with high profile clarity.

In sum, our findings consistently back Hypothesis 1, that the clearer the profile of a party on an issue, the higher the impact of that issue on the vote choice.

While we find clear evidence that party profiles condition the impact of issues on voting propensities, we argue that party profile does not tell the whole story. To get a more comprehensive view of the impact of issue voting, we also need to look at the differences in choice formation at the individual level. Because political sophistication is not distributed homogenously across the electorate, the capacity to receive and process information regarding party profiles is also likely to vary from one voter to another. According to our second hypothesis, the effect of political sophistication is conditional on party profile: it exerts its full impact when party profile clarity is low, but is unlikely to matter when party profile clarity is high.

The results of our estimations appear in Table 2, models 4 to 6 . The effects are hard to grasp based on the coefficients, since they are embedded in a complex set 


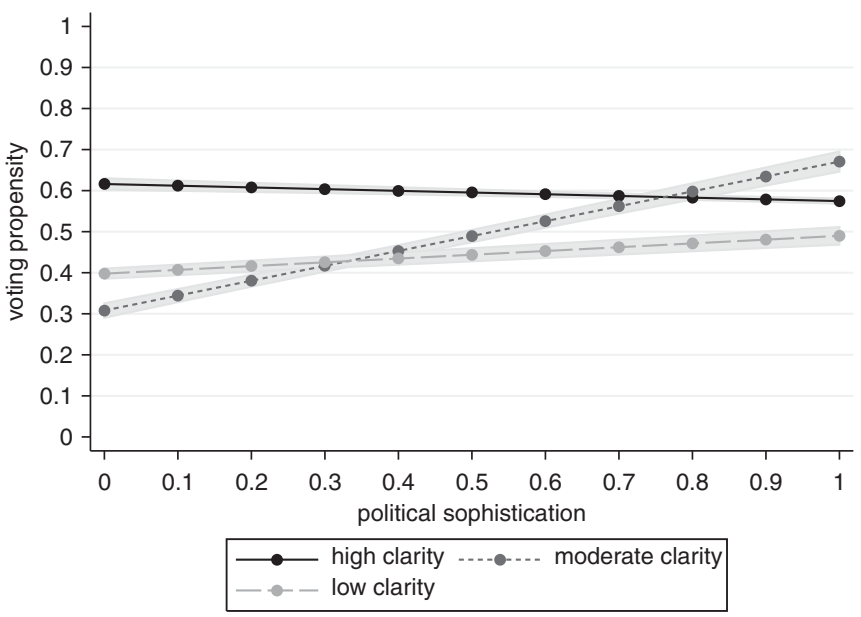

Figure 4 Impact of left-right dimension on vote propensity, as a function of political sophistication.

of interactions between party profile, issue preferences and sophistication. ${ }^{15}$ Therefore, we turn to a graphical presentation of the results (Figures 4-6): For each level of profile clarity we plot the estimated impact of a given issue on voting propensity ( $y$-axis) as a function of voters' political sophistication ( $x$-axis), and for a given voter-party distance. ${ }^{16}$

Starting with our synthetic measure of issue conflict (voter-party distance on the left-right scale), Figure 4 shows that sophistication does indeed play a different role depending on party profile clarity. With high party profile clarity, we do not witness any difference in the impact of voter-party distance on the left-right scale on the voting propensities of more and less sophisticated voters. By contrast, if profile clarity is moderate, citizens' political sophistication matters considerably: the estimated voting propensity is almost 40 percentage points higher among highly competent than among incompetent voters. However, and in contrast to our expectations, the sophistication-related effects are far lower if party profile clarity is low (the difference in voting propensities amounts to only 10 percentage points between minimal and maximal sophistication). Therefore, the results only partly confirm our hypothesis. On the one hand, the result regarding high clarity profiles is in line with our theoretical expectations: when a party is ideologically clearly profiled, its left-right position

${ }^{15}$ Further, we see that for the left-right criterion and - even more so - for the EU issue criterion, the size of the coefficients regarding political competence - and related interaction terms - is very large. This is, however, not a major concern. First, this is not unusual for models including a series of interactions based on dummy variables, especially interactions of the third order as in Table 2. Second, according to a widespread view, interaction models should be interpreted based on graphical representation, rather than coefficients (e.g. Friedrich, 1982; Franzese et al., 2001; Bambor et al., 2006).

16 Voter-party distances on the issue scales are kept constant at their respective mean. 


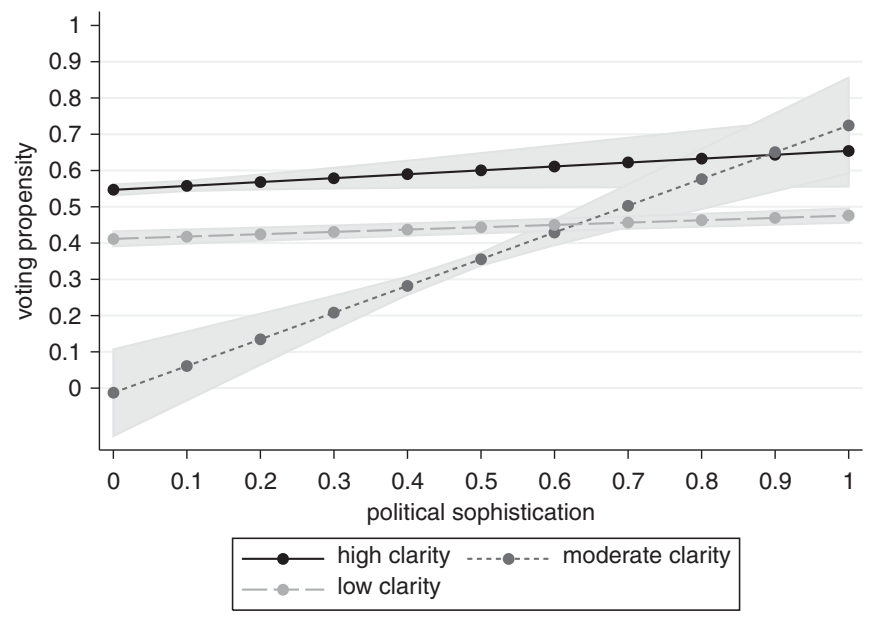

Figure 5 Impact of the EU membership issue on vote propensity, as a function of political sophistication.

is so well known that even political novices are able to identify it. As a consequence, political sophistication does not (cannot) exert any mediating effect. On the other hand, the influence of political sophistication seems to peak where a party profile is moderately clear - and cease to matter where a party profile is unclear.

Interestingly enough, the results regarding the EU membership issue and the fiscal issue tell a similar story, that is, they suggest that the impact of political sophistication is highest when a party's profile is moderately clear. With respect to the EU membership issue (model 5 and Figure 5), the effect of political sophistication is paramount if a party's profile is moderately clear: The estimated voting propensity increases from 0 among political novices to $70 \%$ among highly sophisticated voters. By contrast, there is no difference between incompetent and competent voters when the clarity of a party's profile is either low or high. Similarly, with respect to the taxation issue (model 6 and Figure 6) the only situation where sophistication matters (to some extent) is when a party's profile is moderately clear.

In sum, our empirical tests provide overall support for our expectation that political sophistication will not have a standard impact on the use of decisionmaking criteria, but that its impact will vary according to party profile clarity. However, the results are not fully in line with Hypothesis 2. On the one hand, our data confirms that a very clear profile has a disruptive effect on the influence of political sophistication, meaning that it cancels this influence out: for each and every issue there is no difference in issue impact between sophisticated and nonsophisticated voters when the party profile clarity is high. This does not mean that these issues do not matter for the vote choice, but that they matter differently according to the level of political sophistication. When a party's profile is especially clear, even novices are able to evaluate that party based on the corresponding issue. 


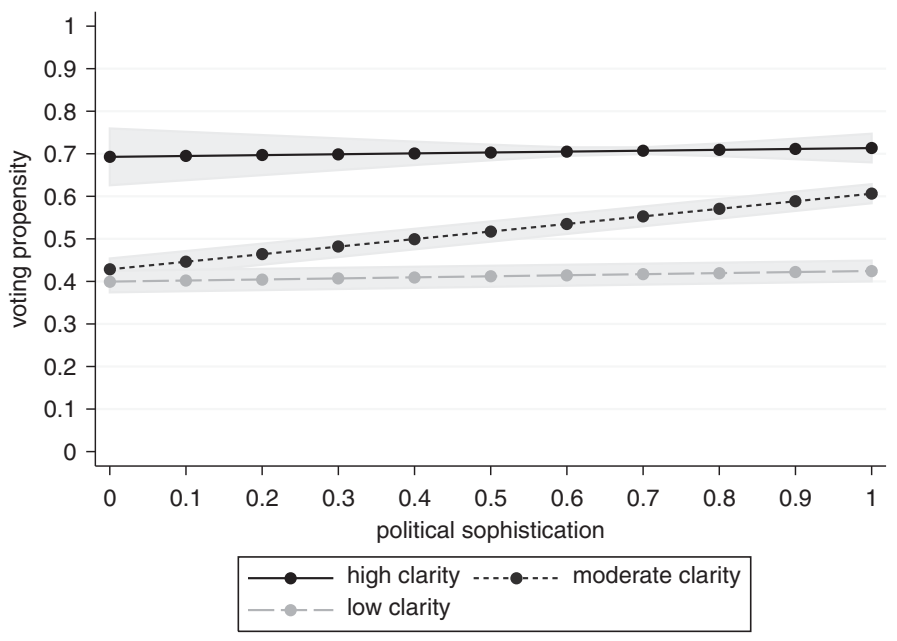

Figure 6 Impact of the fiscal issue on vote propensity, as a function of political sophistication.

In other words, a party that adopts a clear position on an issue can make sure that almost nobody will miss its position. As a result, both competent and noncompetent voters will be able to use that issue as a criterion when making their electoral choice for (or against) the party. This situation certainly comes closest to what Key (1966) had in mind when he asked parties for clear alternatives: the clarity of a party profile can, so to say, compensate for a lack of political sophistication among the electorate and increase the likelihood that voters will vote in a responsible way.

On the other hand, we do not witness the anticipated sophistication-related effects when party profile clarity is low for any of our three issues. Unexpectedly, political sophistication exerts its full effect when party profile clarity is moderate. This leads us to a refinement of our hypothesis: the impact of political sophistication on the strength of issue voting does not decrease in line with the clarity of a party's profile, but is curvilinear. It is highest for parties with a moderately clear profile. By contrast, when a party's profile is unclear, political sophistication hardly plays any role. As a possible explanation for this, one may point to the fact that when a party lacks any profile on a given issue, the signals sent to the voters are so indistinctive and so ambivalent that even the most sophisticated voters are unable to evaluate the party and decide whether they support it or not. This prevents political sophistication from playing its mediating role in the process of electoral choice. ${ }^{17}$

\footnotetext{
17 Note that these results remain very similar if we use a measure of political sophistication based on the cognitive (knowledge) dimension only. As shown in Figures 4 to 6, the effect of sophistication on the strength of issue voting is curvilinear, that is, sophistication plays a role only when party profile clarity is moderate.
} 


\section{Conclusion}

In this paper we have examined how party profile clarity regulates the use of decision-making criteria among voters. Inspired by Key's famous claim, we have assumed that the impact of issue preferences on the vote choice depends on the clarity of the alternatives presented to voters. Our contribution to the literature is threefold. First, by looking at the role of party profile we add to the literature emphasizing the importance of party characteristics for electoral choice (van der Eijk and Franklin, 1996; Franklin and De Sio, 2012; Walczak and van der Brug, 2012). Second, by combining data from the supply and demand sides we offer a more comprehensive account of electoral choice. Third, in addition to differences across parties, we have also analysed how heterogeneity among voters with respect to political sophistication conditions the relationships between party profile and the use of decision-making criteria. By examining higher order interactions with political sophistication, we advance the understanding of the process of party choice formation.

Voters are not fools. As V. O. Key suggested more than 40 years ago voters are able to behave rationally and responsibly, provided that political parties present clear choices to them. Our results provide strong support for the hypothesis that the extent of reliance on a given issue closely depends on how clearly profiled a party is on that issue: the clearer the party profile, the stronger the impact of the corresponding issue on voting propensities. The fact that our results hold for a variety of issues increases their validity.

The findings regarding the mediating role of political sophistication result in a refinement of our second hypothesis. As expected, the impact of political sophistication varies as a function of party profile clarity. However, while we hypothesized that sophistication-induced effects would increase as the party profile clarity decreased, our findings show that sophistication matters most when a party's profile is moderately clear. Under such conditions the higher the political sophistication, the higher the impact of issue voting. By contrast, if a party's profile is (too) unclear, the strength of issue voting does not differ markedly between competent and noncompetent voters - presumably because even the most competent voters find it difficult to evaluate the party. Similarly, individual sophistication plays no role if a party's profile is clear. In such a situation, all voters are able to evaluate the party, irrespective of their level of political sophistication. This latter result fits nicely with - and refines - Key's argument: the risk that less sophisticated voters vote arbitrarily only exists when parties do not provide clear alternatives and, therefore, do not enable them to cast a reasonable vote. More generally, our findings regarding the conditional role of political sophistication speak to the literature on political sophistication (e.g. Rivers, 1988; Zaller, 1992; Kuklinski et al., 2001), and confirm the utmost importance of voters' sophistication in the process of electoral choice.

Besides their scientific implications, our findings also have practical implications. The importance of the clarity of political alternatives highlights the responsibility of 
political parties. Indeed, their ability to defend clear issue positions, that is, positions that are both distinguishable from each other and widely shared among members, appears as a crucial factor. If parties have a clear issue profile, then it is easier for voters to make up their minds and support the party that is closest to their preferences. By contrast, if a party's profile on a given issue is unclear, then this issue will be of little help for voters, even the most sophisticated, who will have hard time evaluating the party based on that issue.

In the Swiss context, the Swiss People's party is the party that overall displays the clearest issue profile. This very clear profile, in turn, is a direct consequence of the party's transformation into a right-wing populist party over the last 2 decades. Seen from the perspective of party choice formation, this strategic reorientation has had two important consequences. First, by increasing the clarity of the party's profile, it has clarified political options for voters. Second, and for the same reason, it has reduced the effect of political sophistication on the decision-making choice for that party.

Of course, the fact that our results are based on five parties only and cover a single country means we must be cautious. The results are still tentative and need to be replicated in other contexts. This said, the fact that our hypotheses hold in a country that, due to its consensual character and to the high development of direct democratic institutions, can be seen as a least likely case with respect to the impact of issue preferences on vote choice increases the confidence in our findings. That is, we can reasonably expect that our results regarding the conditional role of party profile and voters' sophistication also hold in other countries with a multiparty system. Applying our model to elections in other contexts and to a larger set of political parties is thus the natural step forward.

\section{Acknowledgements}

Earlier versions of this paper were presented at the Mannheim Centre for European Social Research and at the Wissenschaftszentrum Berlin. The authors thank the participants as well as the two anonymous reviewers for their helpful comments.

\section{Supplementary material}

To view supplementary material for this article, please visit http://dx.doi.org/ $10.1017 /$ S1755773914000113

\section{References}

Alvarez, R.M. and J. Nagler (1998), 'When politics and models collide: estimating models of multiparty elections', American Journal of Political Science 42(1): 55-96.

Bambor, T., W.R. Clarks and M. Golder (2006), 'Understanding interaction models: improving empirical analyses', Political Analysis 14: 63-82. 
Berelson, B., P. Lazarsfeld and W. MacPhee (1954), Voting: A Study of Opinion Formation in a Presidential Campaign, Chicago: University of Chicago Press.

Bochsler, D. and P. Sciarini (2010), 'So close but so far: voting propensity and party choice for left-wing parties in the Swiss national elections 2003-2007', Swiss Political Science Review 16(3): 373-402.

Budge, I. and D.J. Farlie (1983), Explaining and Predicting Elections: Issue Effects and Party Strategies in Twenty-Three Democracies, London: Allen \& Unwin.

Brunner, M. and P. Sciarini (2002), 'L'opposition ouverture-traditions', in S. Hug and P. Sciarini (eds), Changements de valeurs et nouveaux clivages politiques en Suisse, Paris: L'Harmattan, pp. 179-206.

Converse, P.E. (1964), 'The nature of belief systems in mass publics', in D.E. Apter (ed.), Ideology and Discontent, New York: Free Press, pp. 206-261.

Dalton, R.J. (1984), 'Cognitive mobilization and partisan dealignment in advanced industrial democracies', Journal of Politics 46(1): 264-284.

Delli Carpini, M.X. and S. Keeter (1996), What Americans Know About Politics and Why it Matters, New Haven: Yale University Press.

de Vries, C. (2010), 'EU issue voting: asset or liability? How European integration affects parties' electoral fortunes', European Union Politics 11(1): 89-117.

Downs, A. (1957), An Economic Theory of Democracy, New York: Harper and Row.

Enelow, J.M. and M.J. Hinich (1984), The Spatial Theory of Voting: An Introduction, New York, NY: Cambridge University Press.

Franklin, M. and L. de Sio (2012), 'Party matters: the surprising role of party characteristics in conditioning the bases of electoral support in Europe'. Paper prepared for presentation at the American Political Science Association annual meeting, August 2012, New Orleans.

Franzese, R.J. Jr., C.D. Kam and A.A. Jamal (2001), Modelling and Interpreting Interactive Hypotheses in Regression Analysis, Ann Arbor: The University of Michigan.

Friedrich, R.J. (1982), 'In defense of multiplicative terms in multiple regression equations', American Journal of Political Science 26(4): 797-833.

Green-Pedersen, C. (2007), 'The growing importance of issue competition: the changing nature of party competition in Western Europe', Political Studies 55(3): 607-628.

Holzer, T. and W. Linder (2003), 'Die Wahlentscheidung im Wechselspiel zwischen Parteiidentifikation und Sachfragenorientierung', in P. Sciarini, S. Hardmeier and A. Vatter (eds), Schweizer Wablen 1999, Bern: Haupt, pp. 85-122.

Huber, P.J. (1967), 'The behavior of maximum likelihood estimates under nonstandard conditions', in Lucien M. Le Cam and Jerzy Neyman (eds), Proceedings of the Fifth Berkeley Symposium on Mathematical Statistics and Probability, Vol. 1, Berkeley: University of California Press, pp. 221-233.

Key, V.O. (1966), The Responsible Electorate: Rationality in Presidential Voting 1936-1960, Cambridge: Belknap Press of Harvard University Press.

Kriesi, H. and P. Sciarini (2004), 'The impact of issue preferences on the voting choices in the Swiss federal elections 1999', British Journal of Political Science 34: 725-759.

Kriesi, H., E. Grande, R. Lachat, M. Dolezal, S. Bornschier and T. Frey (2008), West European Politics in the Age of Globalization, Cambridge: Cambridge University Press.

Kuklinski, J.H., P.J. Quirk, J. Jerit and R.F. Rich (2001), 'The political environment and citizen competence', American Journal of Political Science 45(2): 410-424.

Lachat, R. (2007), A Heterogeneous Electorate: Political Sophistication, Predisposition Strength, and the Voting Decision Process, Baden-Baden: Nomos Verlag.

Lachat, R. and P. Sciarini (2002), 'When do election campaigns matter, and to whom? Results from the 1999 Swiss election panel study', in Farrell D.R. and R. Schmitt-Beck (eds), Do Political Campaigns Matter? Campaign effects in elections and referendums, London: Routledge, pp. 41-58.

Lijphart, A. (1999), Patterns of Democracy, New Haven: Yale University Press.

Lutz, G. Elections fédérales (2007): Participation et choix électoral, Lausanne: FORS (Swiss Foundation for Research in Social Sciences).

Neuman, W.R. (1986), The Paradox of Mass Politics: Knowledge and Opinion in the American Electorate, Harvard: Harvard University Press. 
Nicolet, S. and P. Sciarini (eds) (2010), Le destin électoral de la gauche: le vote socialiste et vert en Suisse, Genève: Georg.

Nicolet, S. and C. Mendicino (2010), 'Effet des critères politiques et de la conscience politique sur la probabilité de voter pour le PS et les Verts', in S. Nicolet and P. Sciarini (eds), Le destin électoral de la gauche: le vote socialiste et vert en Suisse, Genève: Georg, pp. 293-329.

Page, B. and R.Y. Shapiro (1992), The Rational Public: Fifty Years of Trends in Americans' Policy Preferences, Chicago: Chicago University Press.

Petrocik, J.R. (1996), 'Issue ownership and presidential elections, with a 1980 case study', American Journal of Political Science 40(3): 825-850.

Rabinowitz, G. and S.E. MacDonald (1989), 'A directional theory of issue voting', American Political Science Review 83(1): 93-121.

Rabinowitz, G., S.E. MacDonald and O. Listhaug (1995), 'Political sophistication and models of issue voting', British Journal of Political Science 25(4): 453-483.

Rivers, D. (1988), 'Heterogeneity in models of electoral choice', American Journal of Political Science 32(3): 737-757.

Schloeth, D. (1998), Vor die Wabl gestellt. Erklärungen des Wablverhaltens bei den Eidgenössischen Wablen 1995, Bern: Haupt.

Sniderman, P., J.M. Glaser and R. Griffin (1990), 'Information and electoral choice', in J.A. Ferejohn and J.H. Kuklinski (eds), Information and Democratic Processes, Urbana, IL: University of Illinois Press, pp. 117-135.

Stimson, J.A. (1985), 'Regression in time and space: a statistical essay', American Journal of Political Science 29(4): 914-947.

Tillie, J. (1995), Party Utility and Voting Behavior, Amsterdam: Het Spinhuis.

van der Brug, W. (2004), 'Issue ownership and party choice', Electoral Studies 23(2): 209-233.

van der Brug, W., C. van der Eijk and M. Franklin (2007), The Economy and the Vote: Electoral Responses to Economic Conditions in EU Countries, Cambridge: Cambridge University Press.

van der Eijk, C. and M. Franklin (1996), Choosing Europe? The European Electorate and National Politics in the Face of Union, Ann Arbor: The University of Michigan Press.

van der Eijk, C., W. van der Brug, M. Kroh and M. Franklin (2006), 'Rethinking the dependent variable in voting behavior: on the measurement and analysis of electoral utilities', Electoral Studies 25(3): 424-447.

Vatter, A. (2009), 'Lijphart expanded: three dimensions of democracy in advanced OECD countries?', European Political Science Review 1(1): 125-154.

Walczak, A. and W. van der Brug (2012), 'The electoral trade-off: how issues and ideology affect party preference formation in Europe', Journal of Elections, Public Opinion and Parties 22(3): 245-268.

White, H. (1980), 'A heteroskedasticity-consistent covariance matrix estimator and a direct test for heteroskedasticity', Econometrica 48(4): 817-838.

Zaller, J.R. (1992), The Nature and Origins of Mass Opinion, Cambridge: Cambridge University Press. 